\title{
Economic value of small-scale sea cucumber fisheries under two contrasting management regimes
}

\author{
Maria Eggertsen $^{1}$, Hampus Eriksson $^{2,3}$, Matthew J. Slater $^{4}$, Caroline Ravmond $^{1}$ and Maricela de la Torre-Castro $^{5}$
}

\begin{abstract}
Small-scale fisheries supplying tropical sea cucumbers to Asian markets frequently overharvest stocks, incurring unknown loss of economic value. An indication of such value loss can provide economic incentives for better conservation and management. However, "before and after" time-series by which loss could be calculated are generally not available for most sea cucumber fisheries. In this study we provide a snapshot comparison of stocks of three characteristic sea cucumber species in two islands in the Western Indian Ocean: Zanzibar (open-access fishery) and Mayotte (stocks protected since 2004). Our aim is to provide an indication of reference economic value of holothurian populations under two contrasting management regimes. Comparisons were made from stock appraisals using transects, linked to the species-specific market value, and compared between similar habitats from both locations. Surveyed habitats in Mayotte held sea cucumber stocks with a mean economic value of USD556.90 $\pm 110.30 /$ ha, compared with USD1.73 $\pm 0.58 /$ ha in Zanzibar. A 5\% harvest of sea cucumbers from surveyed areas in Mayotte would yield about 20 times greater income than harvesting the total surveyed stock in Zanzibar. By illustrating the economic value when strong management measures are implemented, this study highlights existing economic values and shows that sea cucumber fisheries in the tropics are a resource worth investing in and with high potential for social-economic benefits if properly managed.
\end{abstract}

Key Words: bêche-de-mer; conservation; ecosystem valuation; invertebrate fisheries; overfishing; sea cucumbers; small-scale fisheries

\section{INTRODUCTION}

Unsustainable exploitation of marine resources decreases ocean biodiversity and undermines long-term utilization of living resources for a growing global human population (Worm and Branch 2012, Pitcher and Cheung 2013, FAO 2018). Poor management of fisheries is coupled with loss of economic benefits worth approximately US\$50 billion annually (World Bank 2009); and since $90 \%$ of fishers live in developing countries, the impact on the poor is especially critical (Mills et al. 2011, Teh et al. 2013). Recognizing and quantifying the economic value of natural resources allows policy and management needs to be identified and aids the evaluation of the economic potential of the resource in question (Costanza and Daly 1987).

Small-scale fisheries for tropical sea cucumbers (Holothuroidea: Aspidochirotida) have a long history and tradition in many nations (Conand 1989). Sea cucumber fisheries have a significant capacity to drive coastal economies (Toral-Granda et al. 2008) and involve approximately 3 million people globally (Purcell et al. 2013). Over 60 species of sea cucumber are targeted, ranging from high to low commercial value, depending on taste and consumers' preferences in Asia, where the refined product is commonly sold as bêche-de-mer (Purcell 2014). Sea cucumber fisheries provide a fitting example of small-scale fisheries because they are widespread, multispecies, and generally involve artisanal methods with simple boats and cheap fishing gear (Uthicke and Conand 2005, Eriksson et al. 2012a, 2015, Purcell et al. 2013, Slater et al. 2013).

Sea cucumbers are rarely consumed locally. Strong demand from Asia drives global expansion and intensification of these fisheries (Purcell et al. 2013). Like many other coastal resources and ecosystem services, the benefits of sea cucumber stocks, when exploited, are highly variable in terms of provision of human well- being. Different actors involved in the sea cucumber commodity chain benefit unevenly (Daw et al. 2016). Nonetheless, sea cucumber fisheries are exceptional in that their entire economic value is based on direct product export. Development of these fisheries follows a boom-bust-ban pattern that generally outpaces the ability of institutions to adapt and implement controls before stocks are negatively impacted (Perry et al. 1999, Anderson et al. 2011, Eriksson et al. 2015). Recovery of overfished stocks is influenced by multiple unpredictable factors, such as recruitment success, mortality, and connectivity (Uthicke et al. 2004, Friedman et al. 2011, Eriksson and Byrne 2015), and by the degree of intensity and time span of fishing pressure (Neubauer et al. 2013). In addition, institutional capacity and management legitimacy and control are needed. Decades of intense fishing of sea cucumbers have led to the listing of seven species as endangered (Apostichopus japonicus, Holothuria scabra, $H$. lessoni, H. nobilis, H. whitmaei, Isostichopus fuscus, and Thelenota ananas; Purcell et al. 2014), with the listing of key traded sea cucumber species an ongoing topic of debate.

Sea cucumber abundance and biomass have been reported from areas with different levels of fishing effort (see, for example, Purcell et al. 2009, Bellchambers et al. 2011, Friedman et al. 2011). In addition, different management regimes have been examined (Shepherd et al. 2004, Jontila et al. 2018). However, studies that link extraction, economy, and management are rare (but see Purcell et al. 2014). This study contributes to new knowledge by analyzing two stocks under different management regimes. It evaluates sea cucumber abundance in easy-access, near-shore shallow reef flat and lagoon habitats to quantify the difference in commercial stock value. Data were collected in two East African islands, Mayotte and Zanzibar, in the Western Indian Ocean (WIO). Eriksson et al. (2015) analyzed the same islands using a wider survey of less accessible habitats (e.g., depths at $\leq 10 \mathrm{~m}$ ) in

${ }^{1}$ Department of Ecology, Environment and Plant Sciences, Stockholm University, Sweden, ${ }^{2}$ WorldFish, Honiara, Solomon Islands, ${ }^{3}$ Australian National Centre for Ocean Resources and Security (ANCORS), University of Wollongong, Australia, ${ }^{4}$ Aquaculture Research - Technology Transfer, Alfred Wegener Institute Helmholtz Center for Polar and Marine Research, Bremerhaven, Germany, Department of Physical Geography, Stockholm University, Sweden 
three specific areas and looked at status of the natural resource, fishery structure, organization, and management. Eriksson et al. (2015) argued that the history of the fisheries, social aspects, and the capacity to adapt management to resource changes have influenced the present holothurian stocks. Currently, Zanzibar sea cucumber stocks are heavily overexploited whereas Mayotte still hosts large populations. The present study compares these two stocks more thoroughly and aims to estimate the potential economic values that might be lost in a poorly managed situation. It further discusses management extremes (open access with lack of control and monitoring vs. total closures) and a possible "desirable middle way" for long-term resource use.

Specifically, the present study aims to provide an estimation of economic values in equivalent habitats for unfished stocks of sea cucumbers by comparing an area where stocks are protected (Mayotte) with an area that is heavily fished (Zanzibar). The study also provides a reference value of natural, nonexploited holothurian populations by including a location where fishing is prohibited. This is important because over $72 \%$ of global sea cucumber fisheries are fully or overexploited, of which all are data-poor (Purcell et al. 2013). The results of this comparison, although spatially and temporally constrained, are intended to motivate a discussion and a reflection on the value of overexploitation, future losses, and sustainable management regimes.

\section{MATERIALS AND METHODS}

\section{Study approach and sites}

Sea cucumber species distribution and carrying capacities are strongly associated with habitat types (Conand 1989, Bellchambers et al. 2011, Eriksson et al. 2012a); thus, we hypothesize that, within similar habitats in the same biogeographical region, similar abundances of sea cucumbers should be found. This approach has been used by Uthicke et al. (2004), and although additional factors certainly influence holothurian populations, it is suggested that measuring abundance provides a reliable overview. Sea cucumber species are valued differently in global seafood markets, which is why fishers will target high-value species first, then lower value species as those originally sought become depleted, fishing down in a commercially decreasing value spiral. Hence, the market value of stocks is a good indicator of overall status of holothurian populations (Friedman et al. 2008).

Sea cucumber fishing in the WIO in subintertidal areas $(\leq 10 \mathrm{~m})$ is mainly performed by skin or scuba diving, by men (Eriksson et al. 2010, Ochiewo et al. 2010). However, near-shore shallow areas $(<3 \mathrm{~m})$ are subjected to high fishing pressure, with men, women, and children collecting large numbers of invertebrates, including sea cucumbers, each day (Fröcklin et al. 2014). These fisheries have been reported to suffer from declining catches and negatively altered over-all invertebrate abundances (Nordlund et al. 2010, Fröcklin et al. 2014), but the potential effect this might inflict upon sea cucumber stocks only has not been examined.

Three representative commercial species were chosen for the study on the basis of observed presence and fishery/market value. Specific criteria were being commonly found in near-shore, shallow-water, easy-access areas ( $\leq 3 \mathrm{~m}$ depth), and falling within different commercial market value categories: one high-, one medium-, and one low-value species. Holothuria nobilis (black teatfish) is of high economic value, is found in the WIO (Eriksson et al. 2012b), but is poorly suited for fishing because it exhibits slow growth rates (Uthicke and Benzie 2001, Uthicke et al. 2004). Bohadschia atra (tigerfish) is an abundant species of medium economic value, first described in 1999 (Massin et al. 1999). Holothuria atra (lollyfish) is of low economic value and can reach very high abundances in its range across the Indo-Pacific (Bonham and Held 1963, Kerr et al. 1993) and probably in the WIO as well. All three species are commonly harvested throughout their distribution ranges (Conand 2008) including the WIO area (Marshall et al. 2001, Conand and Muthiga 2007, Eriksson et al. 2010), making them good candidates for the study.

The study was conducted in Mayotte Island, a French territory in the Comoros Archipelago, and in Unguja Island in Zanzibar, which is part of the United Republic of Tanzania (Fig. 1). Holothuria nobilis, B. atra and $H$. atra have been recorded at both sites in previous studies by Eriksson et al. (2010, 2012b). A small fishery for sea cucumbers was active in Mayotte from the 1990s until 2004, when it was closed because of fear of overfishing (Prefecture de Mayotte 2004). This area constitutes one of the few larger reef systems in the WIO where sea cucumbers are protected (Eriksson et al. 2012b). Compliance with this fishing ban in Mayotte is high because of strict controls. In Zanzibar, intense commercial fishing has been practiced since at least the 1960s, and approximately 1000 fishers of different ages and genders, using various techniques (wading, skin diving, and scuba diving), are involved in the fishery (Eriksson et al. 2010). Previous studies of sea cucumber fisheries in Zanzibar have described stocks as poorly managed, resulting in heavily overexploited populations (Eriksson et al. 2010, 2012a).

Fig. 1. Maps showing (A) location of study sites, and higher detail of (B) the island of Mayotte $\left(12^{\circ} 50^{\prime} \mathrm{S}, 45^{\circ} 8^{\prime} \mathrm{E}\right)$ and (C) Zanzibar (Unguja Island; $6^{\circ} 8^{\prime} \mathrm{S}, 39^{\circ} 19^{\prime} \mathrm{E}$ ). Sampling areas are indicated with shaded boxes.

A)

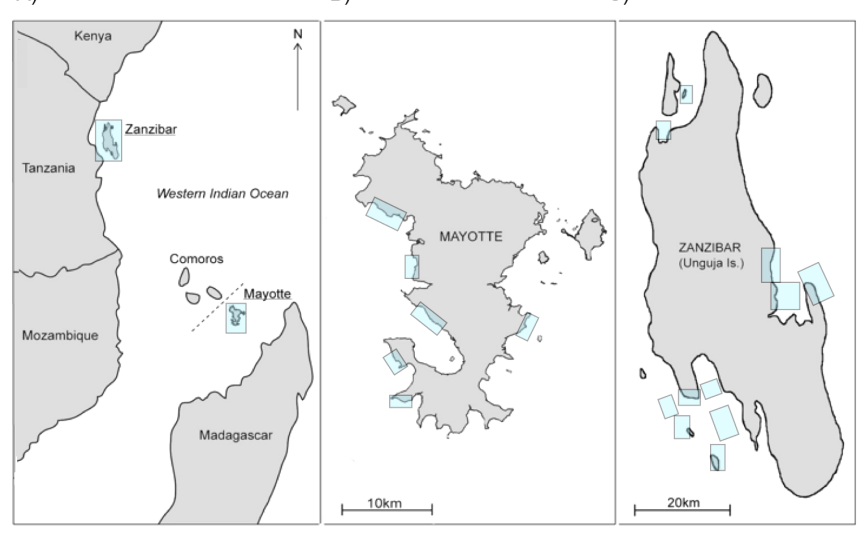

Caddy (2004) suggests that comparing exploited populations with those in marine protected areas (MPAs) can be useful to identify broader indicators of unfished or fished populations of sedentary invertebrates. There are no large shallow-water MPAs in Zanzibar that have had long-term protection; hence, the island of Mayotte was used for comparison. Both islands are located within the same 
biogeographical area, the Somali Basin, regarding holothurian fauna (Samyn and Tallon 2005), and are subjected to a tropical climate, characterized by a warmer rainy season (December to April) and a cooler dry season (May to November; Lugomela et al. 2002, Rolland et al. 2005). Eriksson et al. (2015) found that the differing management regimes between the islands were the main driver of fishery status, and that environmental habitat variables, e.g., oceanic influence, relief, and coral cover, did not explain stock differences. One exception was depth; however, all surveys in the present study were performed in shallow areas $<3$ $m$ in depth, and with no large variations; thus, this variable was not included in the analysis.

\section{Data collection}

Habitat mapping can provide reliable data for spatial analysis of holothurian shallow-water populations, which are closely associated with benthic habitat types (Bellchambers et al. 2011, Eriksson et al. 2012b, Léopold et al. 2013). Sea cucumber abundance was recorded in Zanzibar (269 transects) during June to August 2009, and in Mayotte (186 transects) during April to June 2010, using $40 \mathrm{~m} \times 1 \mathrm{~m}$ transects in near-shore, shallowwater areas ( $<3 \mathrm{~m}$ deep; see Fig. 1). Transects were surveyed by skin diving or walking at low tide. Sea cucumber species and abundances were recorded for each transect. Descriptions of the physical habitat and percentage area of substrates of each transect were also recorded, as described in Eriksson et al. (2012b).

The habitat variable "substrate composition" (percentage hard and soft substrate) associated with species distribution was used to identify comparable transect types in Mayotte and Zanzibar. Mayotte transects were assumed as comparative abundance references for the three species in the study; that is, transects in Mayotte where B. atra, H. atra and/or H. nobilis were encountered were concluded to consist of suitable habitat for that/those species. Transects in Zanzibar consisting of the same substrate composition would therefore potentially accommodate the same species as were found in Mayotte. Of the 186 surveyed transects in Mayotte, 109 comprised such substrate compositions, and of the 269 transects in Zanzibar, a comparable combination of substrate types occurred in 235 (Fig. 2). Bohadschia atra, H. atra and/or H. nobilis were found in 71 of the 109 transects in Mayotte, whereas in Zanzibar at least one of these species were encountered in 16 of the 235 transects.

\section{Commercial economic value estimates}

Commercial value estimates were calculated per transect and per ha for both islands. Because the Mayotte fishery is closed, economic values of sea cucumber species recorded during a market appraisal in Zanzibar during June to August 2009 (Eriksson et al. 2010) were used for both Zanzibar and Mayotte (Table 1). This approach was considered an adequate standardized value for comparison in the current study because both sites are located in the same biogeographical area. The significant socioeconomic differences between the two islands were not considered problematic given that sea cucumbers are not consumed locally at either location, and are considered at both sites as an export commodity providing monetary value only. Hence, similar market dynamics would be expected (particularly if the fishery in Mayotte was open).
Table 1. Economic value of species included in the study.

\begin{tabular}{lcccc}
\hline \hline Species & $\begin{array}{c}\text { Value } \\
\text { category }\end{array}$ & $\begin{array}{c}\text { Value range }^{1} \\
\text { per individual } \\
\text { (TZS) }\end{array}$ & $\begin{array}{c}\text { Value used } \\
\text { (TZS) }\end{array}$ & $\begin{array}{c}\text { Value used }^{\dagger} \\
\text { (US\$) }\end{array}$ \\
\hline $\begin{array}{l}\text { Holothuria } \\
\text { nobilis }\end{array}$ & High & $300-20,000$ & 20,000 & 8.76 \\
$\begin{array}{l}\text { Bohadschia } \\
\text { atra }\end{array}$ & Medium & $150-1000$ & 1000 & 0.44 \\
$\begin{array}{l}\text { Holothuria atra } \\
{ }^{1} \text { Eriksson et al. 2010. }\end{array}$ & Low & $20-150$ & 150 & 0.07 \\
${ }^{\dagger}$ US\$ 1 = TZS 2283 (09/09/2018). & & \\
\end{tabular}

Fig. 2. Comparison of transects from Mayotte (left panels) and Zanzibar (right panels). Shaded blue areas denote transect types (ratio soft:hard substrate) where each species was found in Mayotte, and the assumed suitable habitat for the species at both sites. Number of transects $(\mathrm{n})$ comprising each panel: $\mathrm{A}=$ $70, \mathrm{~B}=113, \mathrm{C}=74, \mathrm{D}=123, \mathrm{E}=108$, and $\mathrm{F}=235$.
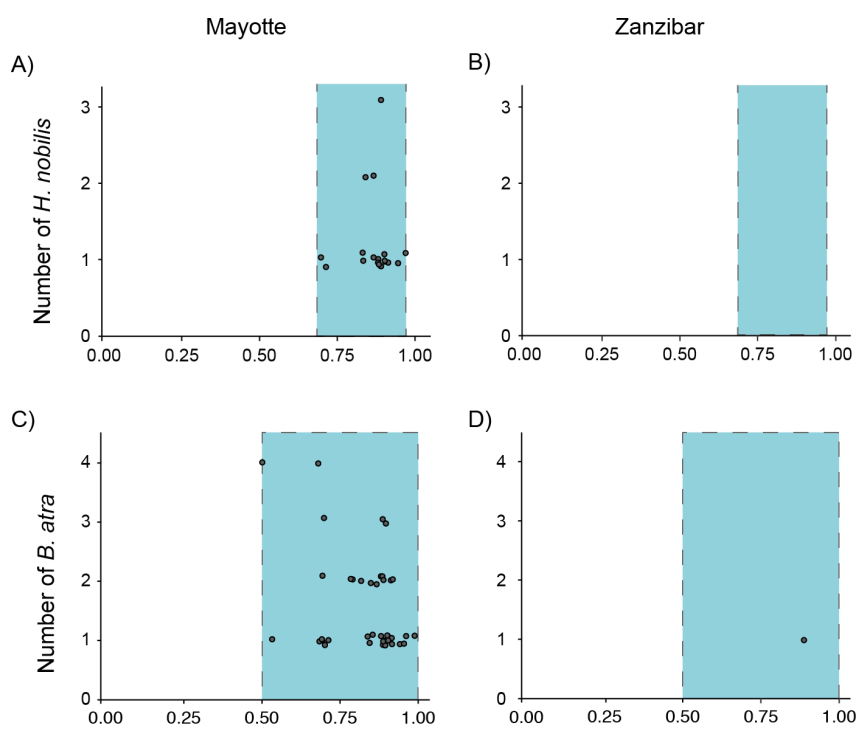

E)

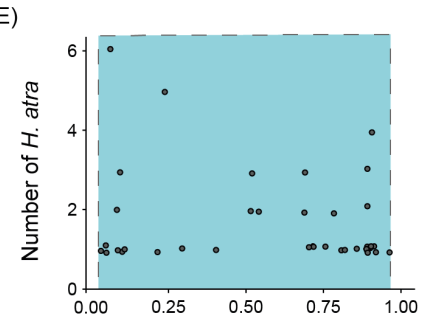

F)

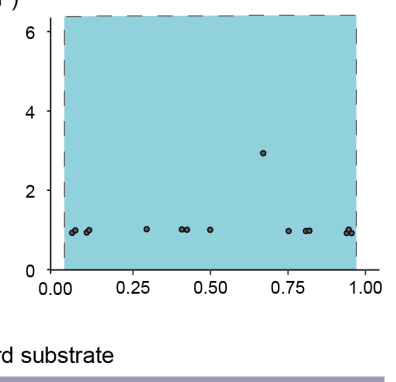

\section{Statistical analyses}

Prior to analyses, all data were tested for homogeneity of variances with Bartlett's K-squared test $(p<0.05)$, and as transformation by $\log _{10}$ and square root did not improve homogeneity, a nonparametric model was chosen. Statistical 
Table 2. Abundance of target species, showing mean values \pm standard error of individuals/transect and calculated per ha. Mean values are calculated for transects defined as having suitable habitat for each individual species based on substrate composition.

\begin{tabular}{lccc}
\hline \hline & Holothuria nobilis & Bohadschia atra & Holothuria atra \\
\hline Mayotte & & Individuals/transect $\left(40 \mathrm{~m}^{2}\right)$ & $0.64 \pm 0.10(n=108)$ \\
Zanzibar & $0.34 \pm 0.12(n=70)$ & $0.84 \pm 0.12(n=74)$ & $0.07 \pm 0.02(n=235)$ \\
& $0(n=113)$ & $0.008 \pm 0.008(n=123)$ & $160 \pm 25$ \\
Mayotte & & & $18 \pm 5$ \\
Zanzibar & $85 \pm 30$ & Individuals/ha & $210 \pm 30$ \\
\hline
\end{tabular}

analyses of differences in economic values and abundances of the three species (all species pooled and species-specific) between sites (Mayotte vs. Zanzibar) were performed using the Kruskal-Wallis rank sum test: nonparametric analysis of variance (ANOVA). Holothuria nobilis was removed in one of the analyses because this species influences the data heavily on account of its very high economic value and absence in Zanzibar.

\section{RESULTS}

\section{Habitat preferences}

In Mayotte, $H$. nobilis (24 individuals) was observed in transects that were dominated by hard substrate, ranging from $70 \%$ to $95 \%$ (Fig. 2A). This species was not recorded in any of the comparable transects in Zanzibar (Fig. 2B). Substrate composition in transects where $B$. atra was observed in Mayotte indicated broader habitat preferences than $H$. nobilis, with B. atra (62 individuals) recorded in habitats with $50 \%$ to $100 \%$ hard substrate (Fig. 2C). Only one specimen of $B$. atra was observed in comparable transects in Zanzibar (Fig. 2D). The habitat of H. atra in Mayotte (69 individuals) ranged from 5\% to $95 \%$ hard substrate (Fig. 2E). The low-value species $H$. atra was the most abundant species in Zanzibar (17 individuals) (Fig. 2F).

\section{Commercial stock comparison for combined species}

At least one of the three target species was recorded in $38 \%$ of all surveyed transects in Mayotte; the corresponding number in Zanzibar was $6 \%$. Although the low-value species H. atra was the most abundant species in both Zanzibar and Mayotte overall (Fig. 2), in Mayotte, B. atra reached higher abundances than $H$. atra in habitats with suitable substrate (Table 2).

Abundance of all three species pooled per transect was significantly higher in Mayotte, as was commercial value $(p<$ 0.001; Table 3). Commercial value extrapolated to value per ha corresponded to a mean \pm standard error (SE) of US\$556.90 \pm 110.30 /ha in Mayotte, which was over 300 times higher than in Zanzibar (US\$1.73 $\pm 0.58 / \mathrm{ha}$ ).

In Mayotte, sea cucumbers with a combined economic value exceeding US\$5.00 were found in 20 transects, while in Zanzibar comparable transects contained sea cucumbers with a combined economic value not exceeding US\$0.44 (Fig. 3). The value range per transect where sea cucumbers of at least one of the three target species were found differed significantly between Mayotte and Zanzibar; values per transect in Mayotte were in the range of US\$0.07-26.80 (1-7 individuals), and in Zanzibar US\$0.07-0.44 (1-3 individuals). This equates to an economic value range of
US\$17.50-6700.00/ha in Mayotte and US\$17.70-110.00/ha in Zanzibar. The difference in economic value is driven primarily by the high-value species $H$. nobilis (> $90 \%$ of total disparity). Because sea cucumbers were found in $38 \%$ of transects in Mayotte and $6 \%$ in Zanzibar, these value ranges are probably an overestimation. According to the occurrence of the different species, a more realistic value range would be US\$6.50-2546.00/ ha in Mayotte and US\$1.10-6.60/ha in Zanzibar.

Fig. 3. Frequency of sea cucumbers in comparable transects by economic value (US\$) in (A) Mayotte $(n=109)$ and (B)

Zanzibar $(n=235)$. All three species are pooled in this figure.

Highest value for a transect in Mayotte was estimated to be US\$26.80, whereas for Zanzibar it was US\$0.44.

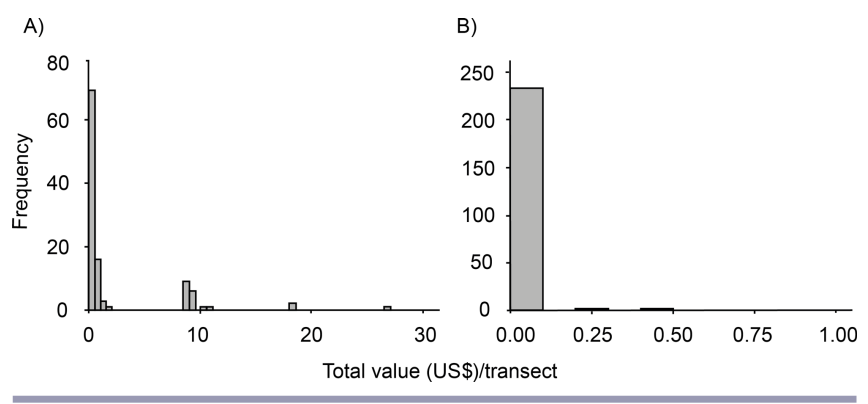

Species-specific commercial stock comparison

Species-specific comparisons between sites in comparable transects showed that economic value was significantly higher in Mayotte for all species $(p<0.001$; Table 3$)$. Holothuria nobilis heavily influences the dataset primarily because of its much higher economic value and absence in Zanzibar; however, a comparison of economic value based only on $B$. atra and $H$. atra shows the same trend $(p<0.001$; Table 3$)$. The largest differences in value were found for the high-value species $H$. nobilis $(100 \%)$, followed by the medium-value species $B$. atra $(98.3 \%)$ and last the lowvalue species $H$. atra $(75.4 \%$; Fig. 4). This translates to a mean ( \pm SE) commercial stock value of US\$751 $\pm 160 /$ ha for $H$. nobilis in Mayotte in habitats with suitable substrate composition, and the other two species considerably lower (Table 4).

\section{DISCUSSION}

Collection of invertebrates, or gleaning, can contribute significantly to overfishing, even if practiced by small-scale, artisanal fishers (Barnes and Rawlinson 2009, Andréfouët et al. 
Table 3. Summary of nonparametric analysis of variance (ANOVA) models (Kruskal-Wallis) comparing economic values of sea cucumbers between Mayotte and Zanzibar.

\begin{tabular}{|c|c|c|c|}
\hline Source of variance & Chi-square & df & $p$-value \\
\hline Total economic value/transect (all species pooled) & $\begin{array}{l}82.154 \\
82.154\end{array}$ & $\begin{array}{l}1 \\
1\end{array}$ & $\begin{array}{l}<0.001 * * * \\
<0.001 * * *\end{array}$ \\
\hline $\begin{array}{l}\text { Economic value/transect (B. atra and } H \text {. atra only, } \\
\text { Site }\end{array}$ & 127.35 & 1 & $<0.001 * * *$ \\
\hline Economic value/transect (species-specific) & & & \\
\hline $\begin{array}{l}\text { Site } \\
\text { Abundance/transect (all species pooled) }\end{array}$ & 190.38 & 5 & $<0.001 * * *$ \\
\hline Site & 79.718 & 1 & $<0.001 * * *$ \\
\hline
\end{tabular}

Fig. 4. Values (US\$) for each sea cucumber species in defined habitats per transect at Mayotte (M) and Zanzibar (Z), (A) Holothuria nobilis, (B) Bohadschia atra, and (C) H. atra. Each circle represents a sample, boxes show median (thick line), 25th and 75 th percentile. Error bars are $95 \%$ confidence intervals. Sample size (n): H. nobilis $=70(\mathrm{M}), 113(\mathrm{Z}) ;$ B. atra $=74(\mathrm{M})$, $123(\mathrm{Z}) ;$ H. atra $=108(\mathrm{M}), 235(\mathrm{Z})$.
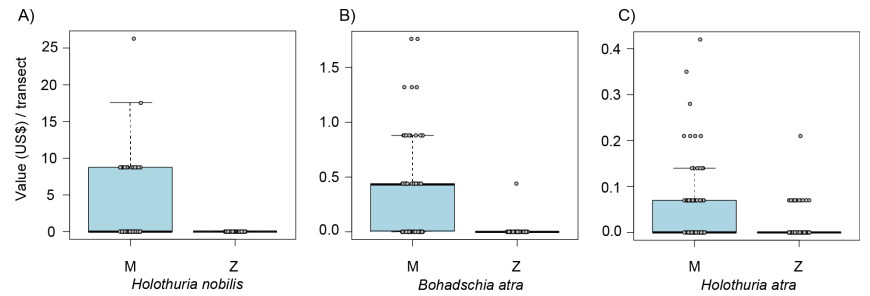

2013, Fröcklin et al. 2014). Gleaning in the intertidal zone involves women, men, and children, and has a substantial negative impact on invertebrate communities in shallow-water habitats in Zanzibar over relatively short periods of time (five years) (Fröcklin et al. 2014). This is especially important in areas with large tidal amplitudes because the shallow seabed is available for collectors working by hand without swimming skills. Furthermore, local communities have few incentives for sustainable harvesting of a marine product that has not been traditionally fished or used for subsistence, and traditional ecological knowledge will likely be lacking. In addition, because the product benefits actors in the fishing and commodity chain differently, the appreciation of the sea cucumber and its related ecosystem services may vary and can complicate valuation and management (see Hicks and Cinner 2014).

To enable effective management of sea cucumber fisheries, evidence and scientific information is needed. Zanzibar lacks baseline data on unfished populations. This is the only study, together with a thesis (Eriksson 2012), that provides essential basic information in combination with economic valuation. There are strong results showing that the abundance of sea cucumbers in the sites is driven by management regimes more than other factors (Eriksson et al. 2015).

\section{Economic value and different exploitation levels}

Sustainable management will most probably result in higher economic value of sea cucumber fisheries in the long term. Fishery closures may be an extreme but necessary measure to preserve vulnerable resources in the face of already inadequate management and high conservation concern (Eriksson et al. 2015). In the current study, a significant difference in stock value exists between short-term protected and exploited areas with similar habitat types in Mayotte and Zanzibar, respectively. The potential value of the fishery in Mayotte is about US\$557/ha based on three representative species, which is approximately 300 times more valuable than in comparable habitats in Zanzibar. All surveyed species were present in significantly higher numbers in protected areas; however, the primary driver of economic difference was the presence/absence of the high-value species $H$. nobilis. The densities of high-value species, disproportionately targeted and depleted in commodity fisheries, is a key factor in determining total stock value (Wells et al. 1983, Jamieson 1993, Uthicke and Conand 2005, Purcell et al. 2014).

\section{Species-specific management considerations}

Sea cucumber species have different life-histories, making them unevenly impacted by fishing. For example, H. nobilis grows comparatively slowly, has a slow recovery rate, and occurs at mean densities around 20 individuals/ha at unfished sites on Australia's Great Barrier Reef (Uthicke and Benzie 2001, Uthicke et al. 2004) whereas H. atra is present at densities between 100 and 690 individuals/ha (Uthicke 2001) and can grow rapidly (Lee et al. 2008). In the current study, protected populations of $H$. nobilis occur naturally at lower densities than both $B$. atra and $H$. atra. In habitats with suitable substrate composition in Mayotte, mean densities were 85 individuals/ha for $H$. nobilis and 160 individuals/ ha for $H$. atra. The highest value and most targeted species in this study, $H$. nobilis, is hence the least abundant and also the least able to withstand fishing impacts based on its life history. Yet, it is commonly managed under the same regulations as other species (FAO 2013). Conservation and fisheries management should therefore consider not only species' ecology, but also be sensitive to species' economic value because this is a powerful driver of overfishing and species selection (Purcell et al. 2014). Thus, species-specific management measures can be of value; however, they remain impractical without rigorous monitoring coupled with species identification training of managers and customs officers (Purcell et al. 2012, FAO 2013). The clear message is that both species composition and commodity price matter for better management.

Recovery of crashed populations of high-value sea cucumbers is predicted to take several decades and will only be possible if 
Table 4. Mean values (US\$) \pm SE per transect and per ha. Mean values are calculated for transects defined as suitable habitat configuration for each individual species.

\begin{tabular}{|c|c|c|c|c|}
\hline & Holothuria nobilis & Bohadschia atra & Holothuria atra & $\begin{array}{c}\text { Total (mean value for all species } \\
\text { pooled) }\end{array}$ \\
\hline \multirow[t]{2}{*}{$\begin{array}{l}\text { Habitat preference } \\
(\% \text { hard substrate) }\end{array}$} & $70-95$ & $50-100$ & $5-95$ & $5-100$ \\
\hline & \multicolumn{4}{|c|}{ Mean value/transect } \\
\hline Mayotte & $3.00 \pm 0.64(n=70)$ & $0.37 \pm 0.05(n=74)$ & $0.04 \pm 0.006(n=108)$ & $2.23 \pm 0.44(n=109)$ \\
\hline \multirow[t]{2}{*}{ Zanzibar } & $0(n=113)$ & $0.004 \pm 0.004(n=123)$ & $0.005 \pm 0.001(n=235)$ & $0.007 \pm 0.002(n=235)$ \\
\hline & \multicolumn{4}{|c|}{ Mean value/ha } \\
\hline Mayotte & $750.90 \pm 160.00$ & $92.50 \pm 12.50$ & $10.00 \pm 1.50$ & $556.90 \pm 110.30$ \\
\hline Zanzibar & 0 & $1.00 \pm 1.00$ & $1.25 \pm 0.25$ & $1.73 \pm 0.58$ \\
\hline
\end{tabular}

sufficiently large areas are closed to fishing (Uthicke et al. 2004). In situations where stocks are severely depleted, active forms of restoration may also be required (Bell et al. 2008). Sustainable annual harvest rates should be as low as $5 \%$ of healthy population standing stocks of high-value reef species, i.e., $H$. whitmaei, the Pacific sister species of $H$. nobilis, based on growth rate estimates (Uthicke et al. 2004), and might also involve restrictions in the size of individuals that can be harvested (Léopold et al. 2013). This is the only available advice for sustainable sea cucumber fishery and equates to an annual extraction value in the range of US\$0.30-127.30/ha from Mayotte (including all three species of this study), considerably higher than that in Zanzibar (US\$0.07$0.33 /$ ha). A $5 \%$ harvest on Mayotte would be more economically valuable than all stocks present in Zanzibar, which suggests that with adequate management, there could be a long-term ongoing fishery benefitting local communities.

\section{Current sea cucumber fisheries management in context}

It is valuable to illustrate and discuss the extreme management situations found in this study. The exact economic value of sea cucumber stocks present in Mayotte (and lost in Zanzibar) is difficult (if not impossible) to calculate, because estimation of the total area of available suitable habitats was not performed, and long-term data are lacking. For the sake of illustration, $40 \mathrm{~m}^{2}$ transect values were extrapolated to abundance per hectare, which may or may not represent reality. Better spatial analyses are thus required to calculate economic values attuned with a deeper analysis of species distribution. In addition, the values in this study are estimated from three species, while 30 other commercial species are also present and form part of the holothurian trade in the WIO (Conand 2008). Therefore, value estimates may vary greatly depending on which species are included in a survey; hence, the present study should be considered as an illustrative example only. Furthermore, economic stock values in Mayotte have accumulated since measures and closures were established, while in Zanzibar exploitation has been ongoing with the social gains of income generated to fishers over decades, but with ecological losses.

The significant difference in commercial stock value and abundance between sites shows that even small-scale, artisanal fisheries driven by strong commercial incentives heavily impact holothurian populations. Recent sea cucumber fishery closures have been reported in 24 countries with different levels of economic development (Purcell et al. 2013), including mainland Tanzania, which has maintained a fishery closure since 2006
(Eriksson et al. 2012c). Mayotte has been closed since 2004; however, Zanzibar is open access and largely unregulated. This lack of regulation in Zanzibar has facilitated fishers from the mainland to evade the closure by selling their catch in Zanzibar (Mgaya and Mmbaga 2007, Eriksson et al. 2012c). The consequences of closures on communities and for fishers have been poorly investigated in Tanzania. It is questionable to what extent total closures are justifiable and in what contexts they are likely to have a socioeconomic benefit. Economic and institutional differences between Zanzibar and Mayotte indicate that the same management regimes cannot fit both islands. In the past, Zanzibar has had a higher degree of reliance on sea cucumber fisheries than Mayotte (Eriksson et al. 2010). However, in a recent study, holothurians were shown to constitute a negligible part of invertebrate harvesters' current livelihoods in Zanzibar's shallow-water areas (Fröcklin et al. 2014). This is probably a sign of the overexploitation of holothurians in Zanzibar over decades. A complete restriction on outtake may thus have varying impacts depending on different geographical setting, scale, type of fishers, and income reliance and might therefore not be an optimal solution. As Daw et al. (2016) point out, the benefits normally vary greatly between human populations. The challenge in this situation is to balance between the two regime extremes of an open-access, unregulated resource and total closure. In the first case, fishers benefit economically but long-term use is jeopardized; in the second, fishers make no economic gains, but ecosystems and diversity benefit. The management goal is to find a balance in which fishers benefit without compromising the resource in the long run.

\section{Practical considerations}

The question as to when it is appropriate to assign economic value to ecological resources is not an easy one to address (Kallis et al. 2013). Fully appraising the values derived from small-scale fisheries is further complicated by their multidimensional nature, with different stakeholders benefitting to different degrees (Garcia et al. 2008). Although many biogeographical conditions are similar in this study's sites, some factors not accounted for may have influenced the comparison; for example, oceanographic properties that can influence productivity (e.g., Williams et al. 2015). In addition, the data analyzed here are not amenable to more applied economic impact evaluation that incorporates multiple other variables associated with utilization or more sophisticated outputs than resource value in primary production (e.g., Gonzáles-Flores et al. 2014). 
The relatively simple approach taken in this study does not diminish the benefit of the analysis; in this study, economic diagnoses of sea cucumber stocks or fisheries performance prove sufficient to provide incentives for new policy and conduct in locations with deteriorated stocks, keeping in mind that over $72 \%$ of global sea cucumber fisheries are fully exploited or worse and severely data-limited (Purcell et al. 2013). An important aspect of this study is to provide reference values and baselines of economic potential and thereby influence future decision making in fisheries management and conservation. A study with a similar goal was conducted in the Western Pacific aiming to "raise awareness of the lost opportunities in the sea cucumber fisheries in Melanesian countries" (Carleton et al. 2013:112). Although actual monetary value was not measured as in the present study, the project report concluded that there is large value to be gained by effectively managing sea cucumber fisheries (Carleton et al. 2013). By illustrating overexploitation with a price tag, the present study adds a new dimension for a more comprehensive understanding about what is lost and what could be gained if these fisheries were better managed.

\section{CONCLUSION}

There is an urgent need to align conservation and development agendas toward more sustainable harvesting of holothurians. The diminished value of overfished stocks means the derived social benefits are highly restricted. Reduced value also means that stocks will not form an economic basis upon which management reforms or transitions in governance can be successfully argued to resource users and managers or implemented. By illustrating the contrasting economic value of strong and weak management measures, this study highlights existing commercial values and shows that sea cucumber fisheries in the tropics are a resource worth investing in and with high potential for socioeconomic benefits if well managed. Calculating primary economic values are a first step to illustrating both present and future gains and losses associated with different management regimes and commercial incentives for species conservation. The extreme and contrasting regimes analyzed here show that large economic and environmental gains can be obtained through finding a middle way.

Responses to this article can be read online at: http://www.ecologyandsociety.org/issues/responses. php/11436

\section{Acknowledgments:}

We thank the two anonymous reviewers for valuable and helpful comments that improved the manuscript. We also thank $\mathrm{Dr}$ Narriman Jiddawi and Muumin Hamad in Zanzibar, Julien Wickel, Alban Jamon, and Leonard Durasnel in Mayotte. The research was funded by Sida, with additional support by Direction de la Agriculture et de la Foret (DAF) and Conseil General, Mayotte.

\section{LITERATURE CITED}

Anderson, S. C., J. M. Flemming, R. Watson, and H. K. Lotze. 2011. Rapid global expansion of invertebrate fisheries: trends, drivers, and ecosystem effects. PLoS ONE 6(3):e14735. https:// doi.org/10.1371/journal.pone.0014735

Andréfouët, S., M. M. M. Guillaume, A. Delval, F. M. A Rasoamanendrika, J. Blanchot, and J. H. Bruggemann. 2013. Fifty years of changes in reef flat habitats of the Grand Récif of Toliara (SW Madagascar) and the impact of gleaning. Coral Reefs 32(3):757-768. https://doi.org/10.1007/s00338-013-1026-0

Barnes, D. K. A., and K. A. Rawlinson. 2009. Traditional coastal invertebrate fisheries in south-western Madagascar. Journal of the Marine Biological Association of the United Kingdom 89 (8):1589-1596. https://doi.org/10.1017/S0025315409000113

Bell, J. D., S. W. Purcell, and W. J. Nash. 2008. Restoring smallscale fisheries for tropical sea cucumbers. Ocean and Coastal Management 51:589-593. https://doi.org/10.1016/j. ocecoaman.2008.06.011

Bellchambers, L. M., J. J. Meeuwig, S. N. Evans, and P. Legendre. 2011. Modelling habitat associations of 14 species of holothurians from an unfished coral atoll: implications for fisheries management. Aquatic Biology 14:57-66. https://doi. org/10.3354/ab00381

Bonham, K., and E. E. Held. 1963. Ecological observations on the sea cucumbers Holothuria atra and $H$. leucospilota at Rongelap Atoll, Marshall Islands. Pacific Science 17(3):305-314.

Caddy, J. F. 2004. Current usage of fisheries indicators and reference points, and their potential application to management of fisheries for marine invertebrates. Canadian Journal of Fisheries and Aquatic Sciences 61:1307-1324. https://doi.org/10.1139/ $\underline{\text { 004-132 }}$

Carleton, C., J. Hambrey, H. Govan, and P. Medley. 2013. Effective management of sea cucumber fisheries and the bêche-demer trade in Melanesia: bringing the industry under rational control. Secretariat of the Pacific Community, Nouméa, New Caledonia. [online] URL: https://spccfpstore1.blob.core.windows. net/digitallibrary-docs/files/fa/faa865a42f2c6f42592705af3af81bab. pdf?sv=2015-12-11\&sr=b\&sig=VAcrx7ChZlTX4pXbapdOU3KAW3BG16TcdgByRfUXiqA $\% 3$ D\&se $=2020-11-27$ T23\%3A52\% $3 \mathrm{~A} 22 \mathrm{Z} \& \mathrm{sp}=\mathrm{r} \& \mathrm{rscc}=$ public $\% 2 \mathrm{C} \% 20 \mathrm{max}-$ age $\% 3 \mathrm{D} 864000 \% 2 \mathrm{C} \% 20 \mathrm{max}-$ stale $\% 3 \mathrm{D} 86400 \& \mathrm{rsct}=$ application $\% 2 \mathrm{Fpdf} \& \mathrm{rscd}=$ inline $\% 3 \mathrm{~B} \% 20$ filename $\%$ 3D $\% 22$ Carleton 13 BDM Management.pdf $\% 22$

Conand, C. 1989. Les holothuries aspidochirotes du lagon de Nouvelle-Calédonie: biologie, écologie et exploitation. Etudes et Thèses 21. ORSTOM, Paris, France.

Conand, C. 2008. Population status, fisheries and trade of sea cucumbers in Africa and the Indian Ocean. Pages 143-193 in V. Toral-Granda, A. Lovatelli, and M. Vasconcellos, editors. Sea cucumbers: a global review of fisheries and trade. FAO Fisheries and Aquaculture Technical Paper No. 516. Food and Agriculture Organization of the United Nations, Rome, Italy.

Conand, C., and N. Muthiga, editors. 2007. Commercial sea cucumbers: a review for the western Indian Ocean. WIOMSA Book Series No. 5. Western Indian Ocean Marine Science Association, Zanzibar, Tanzania.

Costanza, R., and H. E. Daly. 1987. Toward an ecological economics. Ecological Modelling 38:1-7. https://doi.org/10.1016/0304-3800 (87)90041-X 
Rolland R., V. Boullet, J.-P. Quod. 2005. Contribution à la mise en oeuvre de l'inventaire ZNIEFF à Mayotte - Biodiversité et evaluation patrimoniale. Direction de l'Agriculture et de la Forêt (DAF) and Conservatoire Botanique National (CBN) Mascarin. [online] URL: http://docplayer.fr/20960093-Mayotte-biodiversiteet-evaluation-patrimoniale.html

Daw, T. M., C. Hicks, K. Brown, T. Chaigneau, F. JanuchowskiHartley, W. Cheung, S. Rosendo, B. Crona, S. Coulthard, C. Sandbrook, C. Perry, S. Bandeira, N. A. Muthiga, B. SchulteHerbrüggen, J. Bosire, and T. R. McClanahan. 2016. Elasticity in ecosystem services: exploring the variable relationship between ecosystems and human well-being. Ecology and Society 21(2):11. https://doi.org/10.5751/ES-08173-210211

Eriksson, H. 2012. Managing sea cucumber fisheries and aquaculture. Studies of social-ecological systems in the Western Indian Ocean. Dissertation. Department of Systems Ecology, Stockholm University, Stockholm, Sweden. ISBN 978-91-7447-515-9.

Eriksson, H., and M. Byrne. 2015. The sea cucumber fishery in Australia's Great Barrier Reef Marine Park follows global patterns of serial exploitation. Fish and Fisheries 16:329-341. https://doi.org/10.1111/faf.12059

Eriksson, H., M. Byrne, and M. de la Torre-Castro. 2012b. Sea cucumber (Aspidochirotida) community, distribution and habitat utilization on the reefs of Mayotte, Western Indian Ocean. Marine Ecology Progress Series 452:159-170. https://doi.org/10.3354/ meps09665

Eriksson, H., M. de la Torre-Castro, J. Eklöf, and N. Jiddawi. 2010. Resource degradation of the sea cucumber fishery in Zanzibar, Tanzania: a need for management reform. Aquatic Living Resources 23:387-398. https://doi.org/10.1051/alr/2011002

Eriksson, H., M. de la Torre-Castro, and P. Olsson. $2012 a$. Mobility, expansion and management of a multi-species scuba diving fishery in East Africa. PLoS ONE 7(4):e35504. https://doi. org/10.1371/journal.pone.0035504

Eriksson, H., M. de la Torre-Castro, S. W. Purcell, and P. Olsson. 2015. Lessons for resource conservation from two contrasting small-scale fisheries. Ambio 44:204-213. https://doi.org/10.1007/ $\underline{\text { s13280-014-0552-5 }}$

Eriksson, H., G. Robinson, M. J. Slater, and M. Troell. 2012c. Sea cucumber aquaculture in the Western Indian Ocean: challenges for sustainable livelihood and stock improvement. Ambio 41:109-121. https://doi.org/10.1007/s13280-011-0195-8

Food and Agriculture Organization of the United Nations (FAO). 2013. Report on the FAO Workshop on sea cucumber fisheries: an ecosystem approach to management in the Indian Ocean (SCEAM Indian Ocean), Mazizini, Zanzibar, the United Republic of Tanzania, 12-16 November 2012. FAO Fisheries and Aquaculture Report No. 1038. FAO, Rome, Italy.

Food and Agriculture Organization of the United Nations (FAO). 2018. The state of world fisheries and aquaculture 2018 - meeting the sustainable development goals. FAO, Rome, Italy.

Friedman, K., H. Eriksson, E. Tardy, and K. Pakoa. 2011. Management of sea cucumber stocks: patterns of vulnerability and recovery of sea cucumber stocks impacted by fishing. Fish and Fisheries 12:75-93. https://doi.org/10.1111/j.1467-2979.2010.00384. $\underline{\mathrm{X}}$

Friedman, K., S. Purcell, J. Bell, and C. Hair. 2008. Sea cucumber fisheries: a manager's toolbox. ACIAR Monograph No. 135. Australian Centre for International Agricultural Research, Canberra, Australia.

Fröcklin, S., M. de la Torre-Castro, E. Håkansson, A. Carlsson, M. Magnusson, and N. S. Jiddawi. 2014. Towards improved management of tropical invertebrate fisheries: including time series and gender. PLoS ONE (9)3:e91161. https://doi. org/10.1371/journal.pone.0091161

Garcia, S. M., E. H. Allison, N. J. Andrew, C. Béné, G. Bianchi, G. J. de Graaf, D. Kalikoski, R. Mahon, and J. M. Orensanz. 2008. Towards integrated assessment and advice in small-scale fisheries: principles and processes. FAO Fisheries and Aquaculture Technical Paper No. 515. Food and Agriculture Organization of the United Nations, Rome, Italy.

Gonzáles-Flores, M., B. E. Bravo-Ureta, D. Solís, and P. Winters. 2014. The impact of high value markets on smallholder productivity in the Ecuadorian Sierra: a stochastic frontier approach correcting for selectivity bias. Food Policy 44:237-247. https://doi.org/10.1016/j.foodpol.2013.09.014

Hicks, C. C., and J. E. Cinner. 2014. Social, institutional, and knowledge mechanisms mediate diverse ecosystem service benefits from coral reefs. Proceedings of the National Academy of Science 111(50):17791-17796. https://doi.org/10.1073/pnas.1413473111

Jamieson, G. S. 1993. Marine invertebrate conservation: evaluation of fisheries over-exploitation concerns. American Zoologist 33:551-567. https://doi.org/10.1093/icb/33.6.551

Jontila, J. B. S., H. M. Monteclaro, G. F. Quinitio, S. M. Santander-de Leon, and J. P. Altamirano. 2018. Status of sea cucumber fishery and populations across sites with different levels of management in Palawan, Philippines. Ocean \& Coastal Management 165:225-234. https://doi.org/10.1016/j. ocecoaman.2018.08.025

Kallis, G., E. Gómez-Baggethun, and C. Zografos. 2013. To value or not to value? That is not the question. Ecological Economics 94:97-105. https://doi.org/10.1016/j.ecolecon.2013.07.002

Kerr, A. M., E. M. Stoffel, and R. L. Yoon. 1993. Abundance distribution of holothuroids (Echinodermata: Holothuroidea) on a windward and leeward fringing coral reef, Guam, Mariana Islands. Bulletin of Marine Science 52(2):780-791.

Lee, J., M. Byrne, and S. Uthicke. 2008. The influence of population density on fission and growth of Holothuria atra in natural mesocosms. Journal of Experimental Marine Biology and Ecology 365:126-135. https://doi.org/10.1016/j.jembe.2008.08.003

Léopold, M., N. Cornuet, S. Andréfouët, Z. Moenteapo, C. Duvauchelle, J. Raubani, J. Ham, and P. Dumas. 2013. Comanaging small-scale sea cucumber fisheries in New Caledonia and Vanuatu using stock biomass estimates to set spatial catch quotas. Environmental Conservation 40(4):367-379. https://doi.org/10.1017/S037689291300009X 
Lugomela, C., T. J. Lyimo, I. Bryceson, A. K. Semesi, and B. Bergman. 2002. Trichodesmium in coastal waters of Tanzania: diversity, seasonality, nitrogen and carbon fixation. Hydrobiologia 477:1-13. https://doi.org/10.1023/A:1021017125376

Marshall, N. T., S. A. H. Milledge, and P. S. Afonse. 2001. Trade review: stormy seas for marine invertebrates: trade in sea cucumbers, seashells and lobsters in Kenya, Tanzania and Mozambique. TRAFFIC East, Southern Africa.

Massin, C., R. Rasolofonirina, C. Conand, and Y. Samyn. 1999. A new species of Bohadschia (Echinodermata, Holothuroidea) from the Western Indian Ocean with a redescription of Bohadschia subrubra (Quoy \& Gaimard, 1833). Bulletin de l'Institut Royal des Sciences Naturelles de Belgique, Biologie 69:151-160.

Mgaya, Y., and T. Mmbaga. 2007. Sea cucumbers in Tanzania. Pages 51-56 in C. Conand, and N. Muthiga, editors. Commercial sea cucumbers: a review for the Western Indian Ocean. WIOMSA Book Series No. 5. Western Indian Ocean Marine Science Association, Zanzibar, Tanzania.

Mills, D. J., L. Westlund, G. de Graaf, Y. Kura, R. Willman, and K. Kelleher. 2011. Under-reported and undervalued: small-scale fisheries in the developing world. Pages 1-15 in R. S. Pomeroy and N. L. Andrew, editors. Small-scale fisheries management: frameworks and approaches for the developing world. CABI, Wallingford, UK. https://doi.org/10.1079/9781845936075.0001

Neubauer, P., O. P. Jensen, J. A. Hutchings, and J. K. Baum. 2013. Resilience and recovery of overexploited marine populations. Science 340:347-249. https://doi.org/10.1126/science.1230441

Nordlund, L., J. Erlandsson, M. de la Torre-Castro, and N. Jiddawi. 2010. Changes in an East African social-ecological seagrass system: invertebrate harvesting affecting species composition and local livelihood. Aquatic Living Resources 23 (4):399-416. https://doi.org/10.1051/alr/2011006

Ochiewo, J., M. de la Torre-Castro, C. Muthama, F. Munyi, and J. M. Nthuta. 2010. Socio-economic features of sea cucumber fisheries in southern coast of Kenya. Ocean \& Coastal Management 53(4):192-202. https://doi.org/10.1016/j. ocecoaman.2010.01.010

Perry, I. R., C. J. Walters, and J. A. Boutillier. 1999. A framework for providing scientific advice for the management of new and developing invertebrate fisheries. Reviews in Fish Biology and Fisheries 9:125-150. https://doi.org/10.1023/A:1008946522213

Pitcher, T. J., and W. W. L. Cheung. 2013. Fisheries: hope or despair? Marine Pollution Bulletin 74:506-516. https://doi. org/10.1016/j.marpolbul.2013.05.045

Prefecture de Mayotte 2004. Portant interdiction de l'exploitation des holothuries sur le territoire de la Collectivité Départemental de Mayotte. Arrete No. 32 SG/DAF 12004. Direction de l'Agriculture et de la Fôret, Mayotte.

Purcell, S. W. 2014. Value, market preferences and trade of bechede-mer from Pacific Island sea cucumbers. PLoS ONE 9(4): e95075. https://doi.org/10.1371/journal.pone.0095075

Purcell, S. W., H. Gossuin, and N. N. Agudo. 2009. Status and management of the sea cucumber fishery of la Grande Terre, New
Caledonia. Programme ZoNéCo. WorldFish Center Studies and Reviews No. 1901. The WorldFish Center, Penang, Malaysia.

Purcell, S. W., A. Mercier, C. Conand, J.-F. Hamel, V. M. ToralGranda, A. Lovatelli, and S. Uthicke. 2013. Sea cucumber fisheries: global analysis of stocks, management measures and drivers of overfishing. Fish and Fisheries 14:34-59. https://doi. org/10.1111/j.1467-2979.2011.00443.x

Purcell, S. W., B. A. Polidoro, J.-F. Hamel, R. U. Gamboa, and A. Mercier. 2014. The cost of being valuable: predictors of extinction risk in marine invertebrates exploited as luxury seafood. Proceedings of the Royal Society B281:20133296. https:// doi.org/10.1098/rspb.2013.3296

Purcell, S. W., Y. Samyn, and C. Conand. 2012. Commercially important sea cucumbers of the world. FAO Species Catalogue for Fishery Purposes No. 6. Food and Agriculture Organization of the United Nations, Rome, Italy..

Samyn, Y., and I. Tallon. 2005. Zoogeography of the shallowwater holothuroids of the western Indian Ocean. Journal of Biogeography 32:1523-1538. https://doi.org/10.1111/ j.1365-2699.2005.01295.X

Shepherd, S. A., P. Martinez, M. V. Toral-Granda, and G. J. Edgar. 2004. The Galápagos sea cucumber fishery: management improves as stocks decline. Environmental Conservation 31 (2):102-110. https://doi.org/10.1017/S0376892903001188

Slater, M. J., Y. D. Mgaya, A. C. Mill, S. P. Rushton, and S. M. Stead. 2013. Effect of social and economic drivers on choosing aquaculture as a coastal livelihood. Ocean \& Coastal Management 73:22-30. https://doi.org/10.1016/j.ocecoaman.2012.12.002

Teh, L. S. L., L. C. L. Teh, and U. R. Sumaila. 2013. A global estimate of the number of coral reef fishers. PLOS ONE 8(6): e65397. https://doi.org/10.1371/journal.pone.0065397

Toral-Granda, V., A. Lovatelli, M. Vasconcellos, C. Conand, J. F. Hamel, A. Mercier, S. W. Purcell, and S. Uthicke. 2008. Sea cucumbers: a global review on fishery and trade. SPC Beche-deMer Information Bulletin 28:4-6.

Uthicke, S. 2001. Influence of asexual reproduction on the structure and dynamics of Holothuria (Halodeima) atra and Stichopus chloronotus populations of the Great Barrier Reef. Marine \& Freshwater Research 52:205-215. https://doi. org/10.1071/MF00064

Uthicke, S., and J. A. H. Benzie. 2001. Effect of bêche-de-mer fishing on densities and size structure of Holothuria nobilis (Echinodermata: Holothuroidea) populations on the Great Barrier Reef. Coral Reefs 19(3):271-276. https://doi.org/10.1007/ $\underline{\mathrm{s} 003380000118}$

Uthicke, S., and C. Conand. 2005. Local examples of beche-demer overfishing: an initial summary and request for information. SPC Beche-de-mer information Bulletin 21:9-14.

Uthicke, S., D. Welch, and J. A. H. Benzie. 2004. Slow growth and lack of recovery in overfished Holothurians on the Great Barrier Reef: evidence from DNA fingerprints and repeated large-scale surveys. Conservation Biology 18(5):1395-1404. https://doi. org/10.1111/j.1523-1739.2004.00309.x 
Wells, S. M., R. M. Pyle, and M. N. Collins. 1983. Echinodermata. Pages 539-544 in S. M. Wells, R. M. Pyle, and M. N. Collins, editors. The IUCN invertebrate red databook. International Union for Conservation of Nature (IUCN), Gland, Switzerland.

Williams, I. D., J. K. Baum, A. Heenan, K. M. Hanson, M. O. Nadon, and R. E. Brainard. 2015. Human, oceanographic and habitat drivers of central and western Pacific coral reef fish assemblages. PLoS ONE 10(4):e0120516. https://doi.org/10.1371/ journal.pone.0120516

World Bank. 2009. The sunken billions: the economic justification for fisheries reform. World Bank, Washington, D.C., USA.

Worm, B., and T. A. Branch. 2012. The future of fish. Trends in Ecology \& Evolution 27:594-599. https://doi.org/10.1016/j. $\underline{\text { tree.2012.07.005 }}$ 